\title{
Heilsuhagfræði á Íslandi
}

\author{
Ágúst Einarsson ${ }^{1}$
}

\begin{abstract}
Ágrip
Í greininni er lýst grunnatriðum í heilsuhagfræði. Pættir eins og heilsufar, vellíðan, sjúkdómar, slys og dauði eru algeng viðfangsefni innan heilbrigðispjónustunnar. Í heilsuhagfræði er m.a. lagt fjárhagslegt mat á leiðir til úrbóta. Heilsuhagfræði hefur enn ekki hlotið mikla umfjöllun hérlendis. Í greininni er m.a. lýst grunnlíkönum í heilsugæslu og fjallað er um umfang heilbrigðismála í hagkerfinu hérlendis, svo sem opinber útgjöld og starfsmannafjölda. Einnig er staða heilbrigðismála á Íslandi rædd í samanburði við önnur lönd, einkum Norðurlönd en jafnframt innan OECD. Par kemur m.a. í ljós að staðan í heilsugæslu hérlendis er góð en útgjöld til heilbrigðismála eru veruleg miðað við önnur lönd, sérstaklega sé tekið tillit til tiltölulega lágs aldurs íslensku pjóðarinnar. Að lokum er stuttlega fjallað um fjórar matsaðferðir innan heilsuhagfræðinnar, p.e. lágmarkskostnaðargreiningu, kostnaðarárangursgreiningu, kostnaðarnytjagreiningu og kostnaðarábatagreiningu.
\end{abstract}

\begin{abstract}
The paper describes the base of health economics. Health, well-being, accidents and death are prevalent concepts in the health sector. Health economics is concerned with analysing the financial impact of improvements. Health economics has notbeen given much attention in Iceland. This paper describes basic economic models for production in health care and the major indicators of the health sector in Iceland are explained, e.g. public expenditures and labour participation. The health sector in Iceland is compared with the health sectors of other countries, primarily the Nordic countries, but also the OECD countries. The situation in health care in Iceland is good, but the health expenditures are high compared to other countries, particularly in light of the relative young age of the Icelandic population. Finally, four evaluation methods in the health sector are briefly demonstrated, i.e. minimum-costs-analysis, cost-effectiveness-analysis, cost-utility-analysis and cost-benefit-analysis.
\end{abstract}

JEL-flokkun: D61; H51; I12; I18

Lykilhugtök: Heilbrigðisútgjöld; heilsugæsla; heilsuhagfræði; kostnaðarábatagreining

\footnotetext{
${ }^{1}$ Höfundur er prófessor í Viðskipta- og hagfræðideild Háskóla Íslands.

Tryggva Pór Herbertssyni, Ásgeiri Jónssyni og tveim nafnlausum ritrýnum eru færðar pakkir fyrir gagnlegar ábendingar. Örfáar lagfæringar hafa verið gerðar á greininni síðan prentuð útgáfa tímaritsins kom út.
} 


\section{Inngangur}

Í pessari grein er fjallað um grunnatriði í heilsuhagfræði, grunnlíkönum innan hennar lýst, gerð grein fyrir umfangi heilsugeirans í íslensku hagkerfi, íslensk heilbrigðispjónusta borin saman við pað sem gerist í öðrum löndum, matsaðferðum innan heilbrigðispjónustu lýst og bent er á ýmsar erlendar rannsóknir sem eru áhugaverðar í íslensku samhengi. Ekki hefur mikið verið fjallað um heilsuhagfræði á Íslandi en pó má nefna nokkrar umfjallanir (Davíð Á. Gunnarsson 1979, Dóra Skúladóttir 1981 og Benedikt Árnason 1990). Einnig liggja fyrir ýmsar innlendar rannsóknir á sviði heilsuhagfræði, einkum af hálfu Hagfræðistofnunar Háskóla Íslands, eins og um áfengisneyslu (Kostnaður og tekjur pjóðfélagsins vegna áfengisneyslu árin 1985-1989, 1999) og um slys (Kostnaður vegna slysa á börnum á Íslandi 1999, Kostnaður vegna sjóslysa á Íslandi 1998 og Kostnaður vegna umferðarslysa á Íslandi 1996). Par að auki hefur tannlæknamenntun verið rannsökuð (Tannlæknadeild og arðsemi tannlæknamenntunar 1993).

Skilgreining Alpjóðlegu heilbrigðisstofnunarinnar (WHO) á heilbrigði eða heilsu er ekki aðeins pað að vera laus við sjúkdóma heldur felst almenn vellíðan í hugtakinu heilbrigði (Clewer \& Perkins 1998). Tengsl heilbrigðispjónustunnar við mannréttindi og samhjálp eru mikil og siðfræðileg álitaefni eru mörg. Eftirspurn eftir heilbrigði eða heilsu er afleidd eftirspurn eftir heilbrigðispjónustu. Með heilbrigðispjónustu er átt við allan heilbrigðisgeirann, hvort sem er innan spítala eða heilsugæslustöðva, lyfjameðferð eða forvarnir. Hagkvæmni stærðarinnar er mikil innan heilbrigðispjónustunnar og læknisfræðilegar fagstéttir hafa mikil áhrif við stjórnun. Kostnaður við heilbrigðispjónustu er hár og almennt er talið að aðgangur að henni purfi аð vera almennur (McPuke, Kumaranayake \& Normand 2002 og Santerre \& Neun 1996).

Heilsuhagfræði felst m.a. í fjárhagslegu mati á kostum, aðgerðum eða leiðum, til að undirbúa ákvörðun. Faraldsfræði fjallar um dreifingu, tíðni og áhættu varðandi sjúkdóma og tengist heilsuhagfræði náið. Grunnspurningar hagfræðinnar, um hvað skuli framleitt, í hvaða magni, hvernig og fyrir hvern, eiga vel við innan heilbrigðispjónustunnar. Pess er almennt krafist að heilsugæsla sé árangursrík, hagkvæm, að sannvirði fáist fyrir pau verðmæti sem varið er til hennar og jafnræði gildi í aðgangi. Framleiðslupættir eru takmarkaðir innan heilsuhagfræðinnar eins og annars staðar í hagkerfinu. Hin miklu útgjöld til heilbrigðismála hafa leitt til sífellt betri líkana til að lýsa aðgerðum og undirbúa ákvarðanir (Cichen et al. 1999 og Claxton \& Thompson 2002).

Í heilbrigðisgeiranum er m.a. fjallað um líf einstaklinga, auknar lífslíkur, heilbrigði, meðferð sjúkdóma og dauða. Forgangsröðun er par mikilvæg vegna kostnaðar (Um forgangsröðun í heilbrigðispjónustu 1997 og Kristján Kristjánsson 1995). Vegna mikilla opinberra umsvifa í heilbrigðiskerfinu er forgangsröðunin oftast á ábyrgð stjórnmálamanna, p.e. kjörinna fulltrúa almennings. Fyrir fagstéttir í heilbrigðisvísindum, eins og lækna, er oft erfitt að gera upp á milli leiða, vegna skyldu peirra gagnvart öllum sjúklingum. Pess vegna er heilsuhagfræði mikilvægt hjálpartæki við ákvarðanatöku í heilbrigðisgeiranum. Gæði í heilbrigðispjónustu snúast oft um líf eða dauða einstaklinga enda er mikið lagt upp úr gæðum og 
gæðastjórnun innan heilsuhagfræðinnar (Newhouse 2002, Seplaki 1997, Högni Óskarsson, Páll Torfi Önundarson \& Vilhelmína Haraldsdóttir 1996 og Guðrún Högnadóttir 2001).

Раð er algengt innan heilsuhagfræðinnar að sýna hvað aðgerðir hafa í för með sér sem kostnað á hvert viðbótarlífár sjúklings. Petta kemur t.d. að gagni við stjórn á opinberri heilbrigðispjónustu og á lyfjamarkaði. Heilsuhagfræði getur komið að gagni við stjórnun á spítölum, í stjórnmálaumræðu, við umbætur í fjárhagsáætlun innan stofnunar, við breytingar á greiðslukerfi fyrir heilbrigðispjónustu, við ákvörðun um fyrirkomulag kostnaðarpátttöku, við að auka samkeppni í heilsugæslunni, m.a. með einkaframkvæmd eða einkavæðingu, við að endurskoða lækningaaðferðir og við hönnun á eftirlitskerfi.

Hægt er að draga saman nokkrar spurningar innan heilbrigðisgeirans par sem heilsuhagfræðin kemur að gagni við leit að svörum. Á að gera læknisskoðun á fólki reglubundið einu sinni á ári (en bifreiðar eru til dæmis sendar í skoðun á um tveggja ára fresti)? Á að athuga blóðprýsting í hvert skipti sem fólk kemur inn á heilsugæslustöð? Ætti nýjasta tækið alltaf að vera til á spítölum? Á alltaf að gefa nýjasta og dýrasta lyfið? Eru hinar takmörkuðu auðlindir, svo sem fjármagn og vinnuafl, nýttar á sem bestan hátt? Er mögulegum leiðum lýst á sambærilegan hátt? Er allur kostnaður metinn, t.d. fjármagnskostnaður? Er kostnaður umfram bein útgjöld reiknaður inn í dæmið, p.e.a.s. er komið mat á fórnarkostnaði við pað að nýta tíma, svæði og möguleika á annan hátt en gert er? Er búið að leggja mat á kosti með úrtakstilraunum eða með sambærilegum hætti? Ef pjónusta er aukin og unnið í stærri einingum, hvað vinnst pá við pað og hvaða viðbótarkostnað og ávinning hefur раð í för með sér? Ef dregið er úr pjónustu, hverja snertir pað og hversu mikið myndu kostnaður og ábati minnka? Hefur tímabundin minnkun á pjónustu sjálfkrafa í för með sér sparnað eða parf að fylgja eftir sérstökum aðgerðum eins og lokun á deildum? Hvaða forsendur eru gefnar varðandi bjartsýni eða svartsýni um mögulega niðurstöðu? Hvað myndi kosta að minnka óvissuna sem fylgir aðgerðinni? Er hugsanlegt að með tiltölulega litlum kostnaði við að afla upplýsinga sé hægt að minnka óvissuna verulega? Pessum spurningum og fleiri verður að svara og meta gildi peirra.

Heilsufar er háð ýmsu fleiru en sjúkdómum og heilsugæslu. Heilsufar er til að mynda háð aldri og efnahag. Раð sem gerir heilsuhagfræðina að mikilvægu verkfæri innan heilbrigðispjónustunnar er m.a. pað að mismunandi aðgerðir geta leitt til sömu niðurstöðu; aðgerðir sem hafa ólíkan kostnað í för með sér og lækningatími getur verið misjafn milli aðgerða. Innan læknisfræðinnar er lagt læknisfræðilegt mat á leiðir innan heilsugæslunnar en pað er hagfræðinnar að meta pær leiðir, m.a. út frá fjárhagslegum sjónarmiðum.

\section{Grunnlíkön innan heilsuhagfræðinnar}

Virkni heilsugæslu fer eftir pví hvers eðlis sjúkdómar eru en með sjúkdómi er átt við hvers kyns breytingu á heilbrigðisástandi einstaklings sem leiðir til lakari heilsu. Á mynd 1 sést heilsa sem fall af heilsugæslu fyrir tvo ólíka sjúkdóma. Magn af heilsu er táknað með H og magn af heilsugæslu með g. Með heilsugæslu er átt við hvers konar 
aðgerðir sem er ætlað að bæta heilsu viðkomandi einstaklings og eru pær oftast margpættar og geta t.d. komið fram í breyttri hegðun viðkomandi einstaklings.

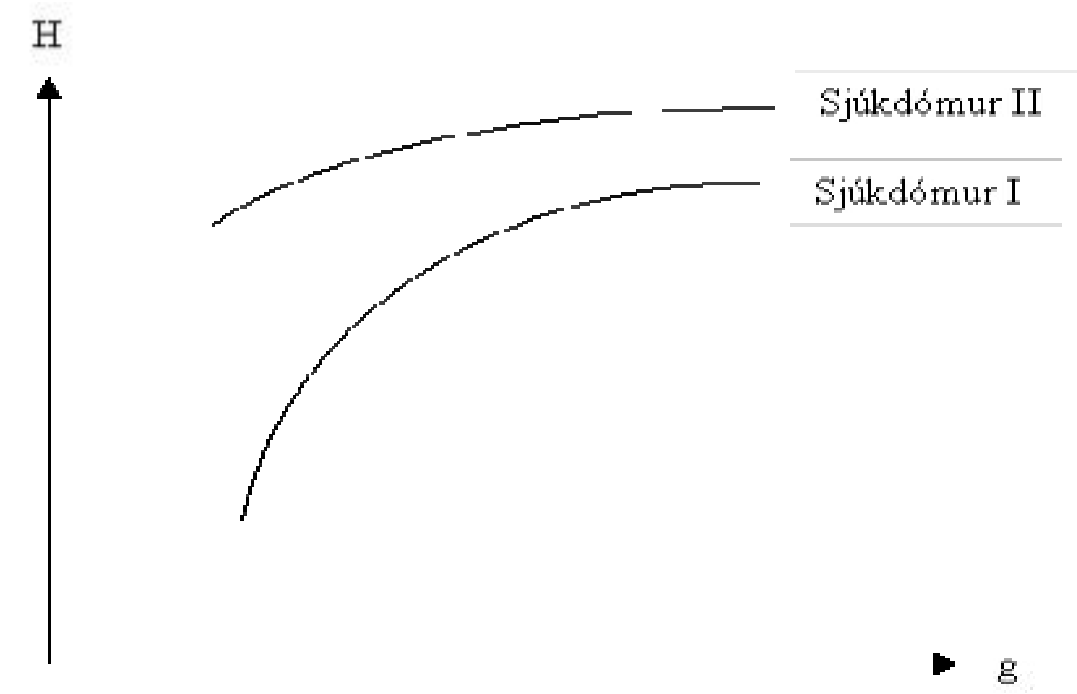

Mynd 1. Heilsufall fyrir tvo sjúkdóma

Sjúkdómur I hefur strax slæm áhrif á heilsuna, t.d. slys, en eftir að meðferð hefst verður hraður bati. Sjúkdómur II hefur hins vegar ekki mikil áhrif á heilsufar og aukin og jafnvel stóraukin heilsugæsla bætir par ekki sérstaklega úr. Kvef er hið sígilda dæmi um slíkan sjúkdóm.

Á mynd 2 sést á stílfærðan hátt hvernig dregur venjulega úr heilsu með hækkandi aldri og hvernig hægt er að lengja ævi einstaklinga með aðgerðum innan heilbrigðispjónustu. Óreglulegur ferill línanna á mynd 2 sýnir sveiflur í heilsu einstaklinga.

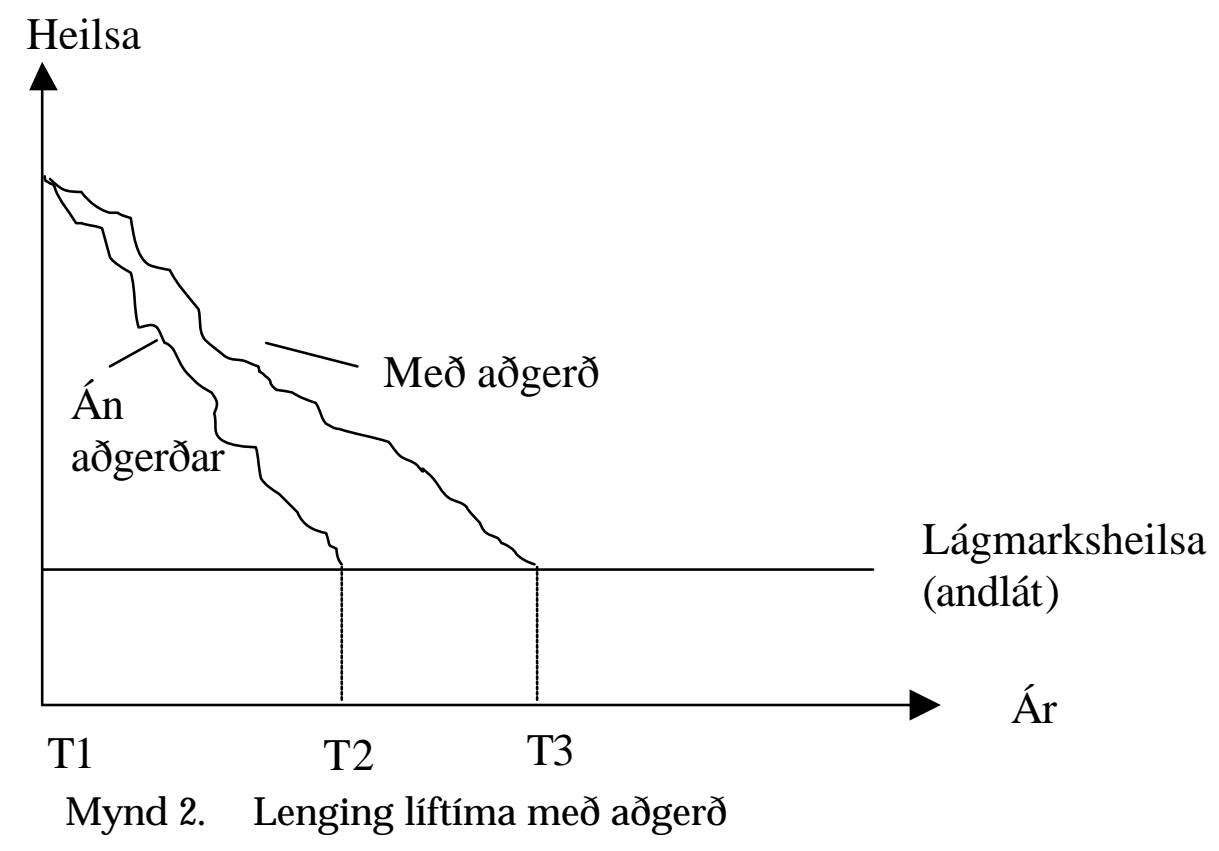

Tíminn er á X-ásnum. T1 er pað ár sem sjúklingurinn veikist. Ef ekkert er gert deyr sjúklingurinn árið T2. Með læknisfræðilegum aðgerðum er hægt að lengja líf 
hans um tiltekinn tíma. Á Y-ásnum er heilsa eða heilsufar hans og hin hallandi lína niður á við sýnir hvernig heilsu hrakar með aldrinum. Með aðgerð er hægt að lengja líftímann og á myndinni er sýnt að með aðgerð er andlátið árið T3. Líftíminn hefur pannig verið lengdur um T3-T2 ár en auk pess hefur heilsan verið bætt á peim árum sem eftir eru ævinnar. Раð аð lengja líftímann er ábatasamt en kostar sitt. Kostnaðurinn er mældur fyrir hvert ár sem hægt er að bæta við líf einstaklings. Viðbótarlífár hefur oft í för með sér fjárhagslegan ábata, t.d. lengri vinnuævi og par með aukið framlag til landsframleiðslunnar.

Hægt er að líta á heilsu og heilbrigði sem hverja aðra vöru og pjónustu (Phelps 1997, og Folland, Goodman \& Stano 2000). Nytjar (utility) eru mældar og táknaðar með $\mathrm{N}$ og magn af öðrum vörum og pjónustu er táknað með A. Nytjafallið er í jöfnu (1).

$$
\text { (j. 1) } \quad \mathrm{N}=\mathrm{f}(\mathrm{H}, \mathrm{A})
$$

Jaðarnytjar fara minnkandi eins og á við aðrar venjulegar vörur. Varan sem er keypt, p.e. heilsugæsla, er pó stórlega niðurgreidd af ríkinu sem bjagar ákvarðanatökuna. Jafngildislína (indifference curve) lýsir samsetningum heilsu og annarra vara sem skila neytandanum sömu nytjum. Hallatala jafngildislínu er $-\mathrm{dN} / \mathrm{dA}$ deilt með dN/dH. Víxlhlutfall (marginal rate of substitution), sem er hallatala jafngildislínunnar, lýsir pví hve mikið önnur gæði purfa að aukast til að bæta upp heilsumissi pannig að neytandinn telji sig jafnsettan.

Раð er hægt að lýsa heilsu sem falli af heilsugæslu og heilsa er pá framleiðsla og heilsugæsla framleiðslupáttur. Í efri hluta myndar 3 er sem dæmi lýst slíku framleiðslufalli, $\mathrm{H}=\mathrm{f}(\mathrm{g})$, (Phelps 1997, bls. 99-101). Á myndinni sést ólík skalahagkvæmni (returns to scale). Í neðri hluta myndar 3 sést jaðar- og meðalheilsa, p.e. jaðar- og meðalframleiðsla, og kúrfa jaðarheilsu sker kúrfu meðalheilsu í hámarki peirrar síðarnefndu.

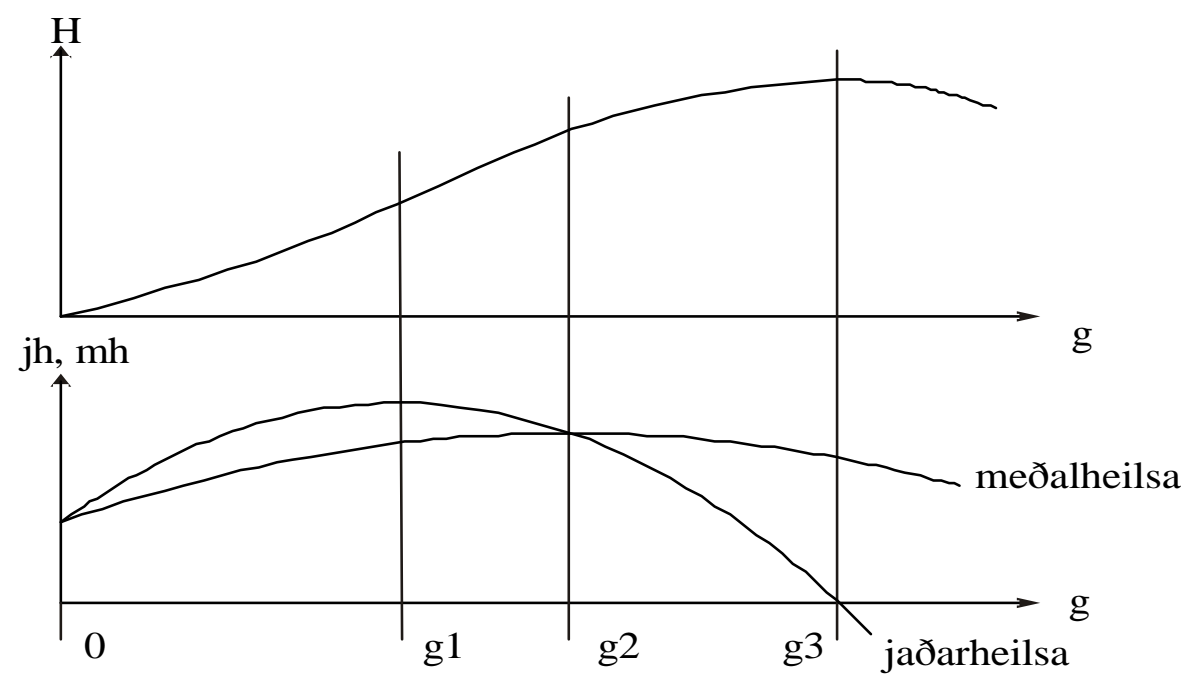

Mynd 3. Framleiðslufall og jaðar- og meðalframleiðsla 
Á svæðinu 0 til g1 eru jaðar- og meðaláhrifin vaxandi, p.e. vaxandi skalahagkvæmni (increasing returns to scale). Frá g1 til g2 eru jaðaráhrifin minnkandi en meðaláhrifin vaxandi. Frá g2 til g3 eru bæði jaðar- og meðaláhrifin minnkandi og eftir g3 eru jaðaráhrifin neikvæð sem pýðir að aukin heilsugæsla dregur úr heilsu, p.e. heilsugæsla utan skynsamlegra marka, t.d. pegar mjög mikil lyfjagjöf dregur úr heilsu. Svæðið frá g1 til g3 er með minnkandi skalahagkvæmni (decreasing returns to scale). Í heilbrigðispjónustu er beiting heilsugæslu venjulega par sem jaðarheilsa er minni en meðalheilsa enda er par jaðarkostnaður hærri en meðalkostnaður. Меð peim forsendum að hver eining af heilsugæslu (g) kosti k kr. og ábati sé sá sami fyrir hverja viðbótarheilsueiningu $(\mathrm{H}), \mathrm{v}$ kr., gildir í kjörstöðu jafna (2) eða að jaðarheilsa við breytingu á heilsugæslu er jöfn einingarkostnaði í heilsugæslu deilt með ábata hverrar heilsueiningar.

$$
\text { (j. 2) } \mathrm{dH} / \mathrm{dg}=\mathrm{k} / \mathrm{N}
$$

Almennt leiða hærri tekjur til aukinnar eftirspurnar eftir heilsugæslu og par með betri heilsu. Um petta er pó ekki hægt að alhæfa, m.a. vegna pess að auknar tekjur geta leitt til óheilbrigðari lífshátta sem hefur slæm áhrif á heilsuna (Phelps 1997). Í próunarríkjunum gæti hins vegar tiltölulega lítil aukning á tekjum bætt heilsu manna verulega par sem um ýmsar grunnparfir er að ræða eins og hreinna vatn, bólusetningar og bætt hreinlæti (Rutherford 2000).

Eftirspurn eftir heilsugæslu sem fall af verði hennar ræðst m.a. af pví hvort viðkomandi veikist eða ekki. Við alvarleg veikindi hliðrast eftirspurnarkúrfan til hægri, p.e. meiri eftirspurn er eftir heilsugæslu við sama verð. Samanlögð einstaklingsbundin eftirspurn mótar heildareftirspurn ípjóðfélaginu. Til að finna eftirspurn eftir heilbrigðispjónustu eru oft gerðar kannanir par sem greiðsluvilji neytenda (willingness to pay) kemur fram. Greiðsluvilji er mikilvægt hugtak innan heilsuhagfræðinnar. Munur á greiðsluvilja og pví verði sem neytandi greiðir er neytandaábati.

Takmarkaðar upplýsingar um áhrif mismunandi leiða innan heilbrigðispjónustunnar geta leitt til aukins kostnaðar en takmarkaðar upplýsingar voru einmitt eitt af fyrstu viðfangsefnum heilsuhagfræðinnar (Arrow 1963). Upplýsingar og meðferð peirra hafa alltaf skipt miklu máli innan heilsugeirans (Porgeir Pálsson \& Ásmundur Brekkan 1999). Vegna ófullkominna upplýsinga, sem oft felast í pví að pær eru ósamhverfar (asymmetric information), par sem eftirspyrjandi (sjúklingur) og framboðsaðili (sjúkrahús) búa yfir mismunandi upplýsingum, hentar hin nýja stofnanahagfræði (New Institutional Economics) vel, p.e. kerfishagfræði eða skipulagshagfræði. Hún byggist á stofnunum (institutions) sem endurspegla leikreglurnar í hagkerfinu par sem rekstrareiningar eða skipulagsheildir (organizations), eins og fyrirtæki eða opinberir aðilar, búa við síbreytilega hegðun einstaklinga, ólík menningarleg áhrif og ófullkomnar upplýsingar (Furubotn \& Richer 1997 og Práinn Eggertsson 1990). Meðal meginsviða hinnar nýju skipulagshagfræði er viðskiptakostnaður (transaction costs), samningafræði (agency theory) og ráðstöfunarréttur (property rights theory) en öll pessi svið falla vel að umfjöllun innan heilsugeirans. 


\section{Hlutur heilbrigðismála í íslenska hagkerfinu}

Heilbrigðispjónusta skiptir verulegu máli í íslensku hagkerfi. Pannig er talið að einstaklingar verji 3,9\% útgjalda sinna í heilbrigðismál sem skiptast jafnt milli heilsugæslu annars vegar og lyfja og lækningavara hins vegar. Petta er svipað og eytt er til kjöt- og fiskkaupa (Landshagir 2001). Á myndum 4 til 6 sjást nokkrir pættir heilbrigðismála í hinu íslenska hagkerfi (Búskapur hins opinbera 1999 og Sögulegt yfirlit hagtalna 2001).

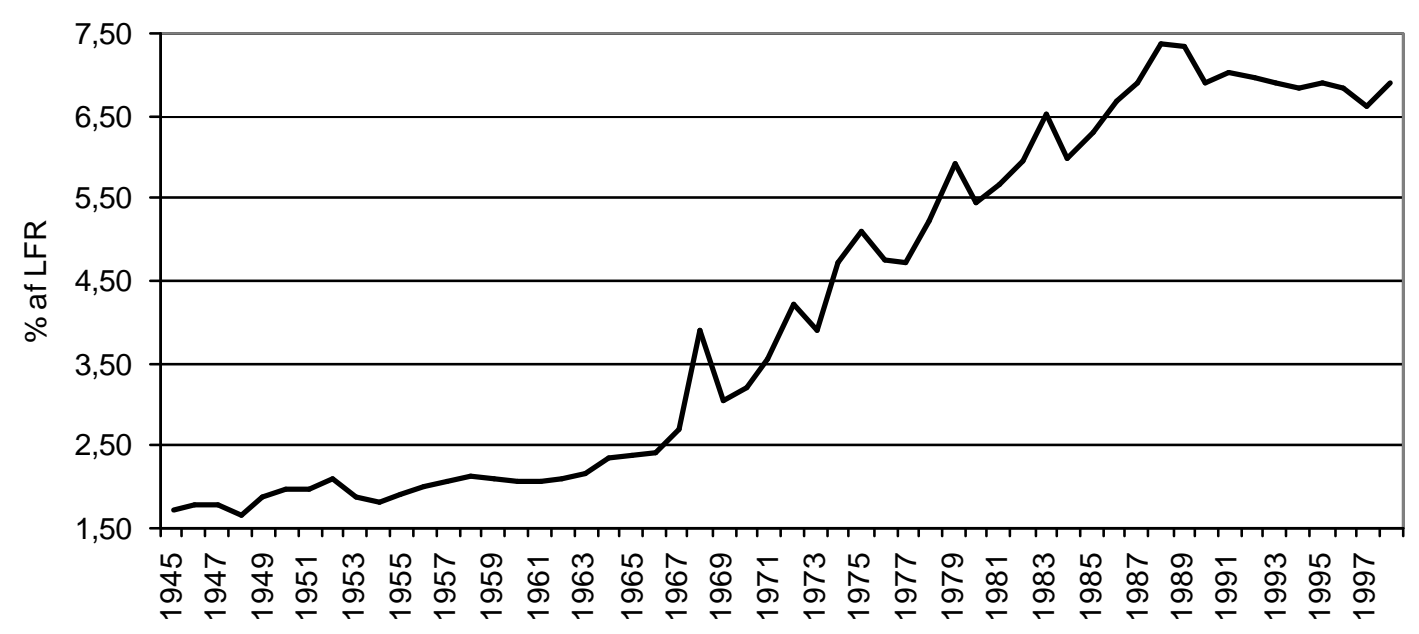

Mynd 4. Opinber útgjöld til heilbrigðismála 1945-1998 sem hlutfall af landsframleiðslu

Á mynd 4 má sjá heildarútgjöld hins opinbera til heilbrigðismála sem hlutfall af landsframleiðslu (LFR) frá 1945 til 1998. Par sést vel hvílíkur vöxtur hefur orðið á pessu sviði. Árið 1945 voru opinber útgjöld til heilbrigðismála sem hlutdeild af landsframleiðslu 1,71\% en urðu hæst 7,37\% árið 1988 en voru árið 1998 6,91\%. Hlutdeildin hafði pannig fjórfaldast á pessum rúmu 50 árum. Opinber útgjöld fóru á pessum tíma úr 15\% landsframleiðslunnar í 38\%. Langmestur hluti útgjalda til heilbrigðismála hérlendis eru opinber útgjöld eða um 85\%.

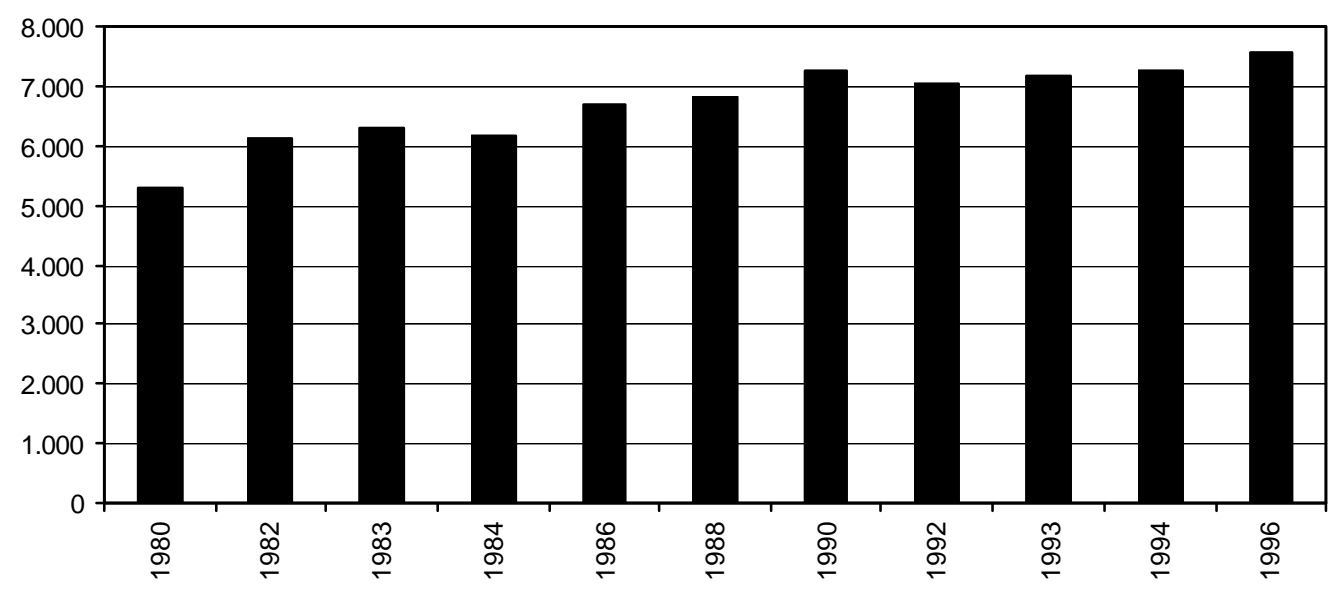

Mynd 5. Fjöldi starfsmanna (ársverk) í heilbrigðisstofnunum 1980-1986

Á mynd 5 sést fjöldi ársverka hjá hinu opinbera á heilbrigðisstofnunum frá 1980 til 1996. Árið 1980 voru ársverkin 5.300 en árið 1996 eru pau orðin 7.600, sem er 43\% 
aukning á 16 árum og er pað um 2,3\% aukning á ári, en pað er meira en tvöföld árleg fjölgun pjóðarinnar á pessum tíma. Hlutdeild hins opinbera á vinnumarkaði fór á pessum tíma úr 15,7\% í 19,8\%. Mikilvægi markvissrar starfsmannastefnu hefur pví eðlilega vaxið verulega innan heilbrigðisgeirans (Magnús Pétursson 2001).

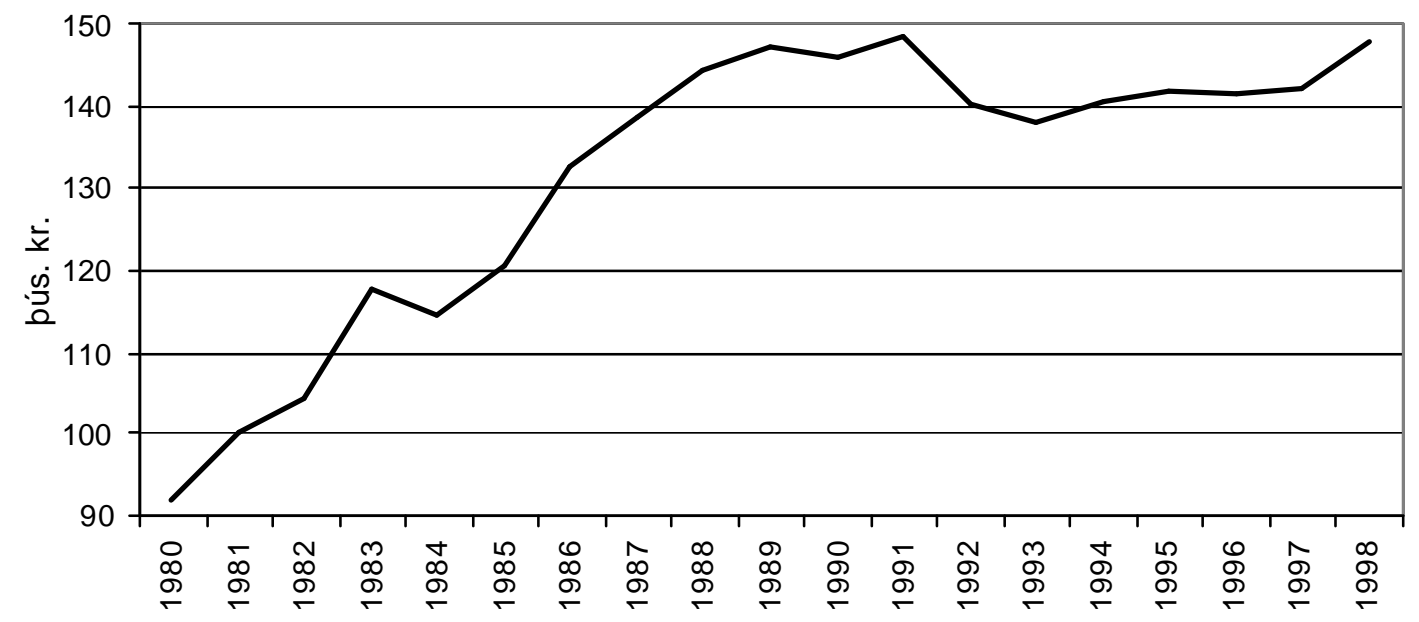

Mynd 6. Opinber heilbrigðisútgjöld á mann 1980-1988 á verðlagi ársins 1998

Á mynd 6 sjást opinber útgjöld til heilbrigðismála á hvern einstakling frá 1980 til 1998 á föstu verðlagi (verðlagi ársins 1998). Útgjöldin fara úr 92 púsundum kr. upp í 148 púsundir kr. og hækka að raungildi um 61\%. Vöxturinn er nær allur fyrri hluta tímabilsins og væri áhugavert að greina hvers vegna hin mikla útgjaldaaukning á 9. áratugnum hættir á peim 10. en til pess pyrfti m.a. að sundurgreina útgjöldin á hvoru tímabili fyrir sig. Opinber útgjöld til heilbrigðismála á árunum 1980 til 1998 á föstu verðlagi (verðlagi ársins 1998) fara úr 20 milljörðum í 40 milljarða eða tvöfaldast og pað er árleg hækkun upp á 3,9\%. Árið 1998 fóru um 18\% opinberra útgjalda til heilbrigðismála. Рað er pví ljóst af pessu að umsvif heilsugeirans eru mjög mikil hérlendis. Раð hefur einnig orðið veruleg raunaukning á útgjöldum ríkisins til heilbrigðismála undanfarin ár. Útgjöld ríkisins til pessa málaflokks eru áætluð 64 milljarðar kr. árið 2003 en pau voru 58 milljarðar kr. árið 1999 á föstu verðlagi (verðlagi ársins 2003), (Frumvarp til fjárlaga 2003 og Peningamál 2002).

Í töflu 1 sést samanburður á milli Landspítala Íslands-háskólasjúkrahúss og nokkurra af stærstu fyrirtækjum landsins árið 2001 (300 stærstu 2002). Par sést að Landspítali Íslands-háskólasjúkrahús ber að mörgu leyti höfuð og herðar yfir aðrar rekstrareiningar hérlendis. Spítalinn er með flest ársverk og hæstar launagreiðslur og veltan er mjög mikil. Opinber framlög til sjúkrahúsa, sem er langdýrasti páttur heilbrigðispjónustunnar, byggjast í meginatriðum á föstum fjárlögum. Í nágrannalöndunum er samhliða föstum fjárlögum greitt á grundvelli kostnaðargreiningar sjúkdómstilvika. Fjármögnun með föstum og breytilegum fjárveitingum og pjónustusamningum hefur margvíslega kosti umfram kerfi sem byggist nær eingöngu á föstum fjárlögum (Fjármögnunarleiðir heilbrigðispjónustu 1998). 
Tafla 1. Landspítali Íslands-háskólasjúkrahús í samanburði við fyrirtæki hérlendis árið 2001

\begin{tabular}{|l|c|c|l|}
\hline \multicolumn{2}{|c|}{$\begin{array}{c}\text { Landspítali Íslands- } \\
\text { háskólasjúkrahús }\end{array}$} & $\begin{array}{c}\text { Í röð af } \\
\text { íslenskum } \\
\text { rekstrar- } \\
\text { einingum }\end{array}$ & \multicolumn{1}{|c|}{ Athugasemdir } \\
\hline $\begin{array}{l}\text { Fjöldi } \\
\text { ársverka }\end{array}$ & 3,883 & 1. sæti & $\begin{array}{l}\text { Næst kemur Baugur með 3.656 ársverk og síðan } \\
\text { Flugleiðir með 2.487 ársverk. }\end{array}$ \\
\hline $\begin{array}{l}\text { Velta í } \\
\text { milljónum } \\
\text { kr. }\end{array}$ & 22.198 & $\begin{array}{l}\text { Á undan eru eftirtalin fyrirtæki og er velta peirra í } \\
\text { milljörðum í sviga: SÍF (61), SH (55), Baugur (42), } \\
\text { Flugleiðir (38), Íslandsbanki (35), Landsbankinn (31), } \\
\text { Alcan á Íslandi (27) og Búnaðarbankinn (22). }\end{array}$ \\
\hline $\begin{array}{l}\text { Laun í } \\
\text { milljónum } \\
\text { kr. }\end{array}$ & 12.399 & 1. sæti & Næst koma Flugleiðir með 8.336 milljónir kr. í laun. \\
\hline
\end{tabular}

\section{Staða heilbrigðismála á Íslandi í samanburði við önnur lönd}

Staða heilbrigðispjónustu er ekki aðeins misjöfn milli landa heldur einnig innan einstakra landa (Spree 1986). Sumt er erfitt að bera saman, m.a. vegna díkra mælingaaðferða og pættir eins og mismunandi aldurssamsetning íbúa skipta miklu máli. Í töflu 2 sést samanburður á nokkrum stærðum innan Norðurlandanna árið 1999 (Health Statistics in the Nordic Countries 1999, 2001).

Tafla 2. Samanburður milli Norðurlanda árið 1999 á nokkrum páttum í heilbrigðisgeiranum

\begin{tabular}{|l|c|c|c|c|c|}
\hline & Danmörk & Finnland & Ísland & Noregur & Svípjóð \\
\hline Náttúruleg fjölgun á hverja 1.000 íbúa & 1,4 & 1,6 & $\mathbf{7 , 9}$ & 3,2 & $-0,7$ \\
\hline Væntanlegur lífaldur við fæðingu & 76,4 & 77,4 & $\mathbf{7 9 , 5}$ & 78,4 & 79,5 \\
\hline $\begin{array}{l}\text { Barnadauði, b.e. börn dáin innan 1 árs fyrir hverjar } \\
1.000 \text { fæðingar }\end{array}$ & 5,6 & 3,6 & $\mathbf{2 , 4}$ & 3,9 & 3,4 \\
\hline Hlutfall beirra yfir 15 ára aldri sem ekki reykja & 65 & 77 & $\mathbf{7 5}$ & 67 & 81 \\
\hline $\begin{array}{l}\text { Áfengisneysla í lítrum af 100\% vínanda hjá beim } \\
\text { sem eru yfir 15 ára aldri }\end{array}$ & 11,6 & 8,7 & $\mathbf{5 , 9}$ & 5,5 & 6,1 \\
\hline $\begin{array}{l}\text { Fjöldi nýrra krabbameinssjúklinga á hverja 1.000 } \\
\text { íbúa }\end{array}$ & 3,4 & 2,5 & $\mathbf{2 , 8}$ & 2,8 & 2,7 \\
\hline Meðallegudagar á sjúkrahúsi (allir sjúkdómar) & 5,6 & 4,5 & $\mathbf{6 , 3}$ & 6 & 5,5 \\
\hline $\begin{array}{l}\text { Fjöldi útskrifaðra af sjúkrahúsi eftir hjartaáfall } \\
\text { (meðallegudagar) }\end{array}$ & $\begin{array}{l}204,0 \\
(-6,7)\end{array}$ & $\begin{array}{l}239,0 \\
(-8,3)\end{array}$ & $\begin{array}{c}\mathbf{2 0 2 , 0} \\
\mathbf{( - 1 0 , 7 )}\end{array}$ & $\begin{array}{c}212,0 \\
(-7,7)\end{array}$ & $\begin{array}{c}313,0 \\
(-6,7)\end{array}$ \\
\hline Sjálfsmorð á hverja 100.000 íbúa & 24,7 & 38,3 & $\mathbf{2 0 , 8}$ & 17,8 & 20,1 \\
\hline $\begin{array}{l}\text { Starfsfólk í fullu starfi í heilbrigðispjónustu fyrir } \\
\text { hverja 100.000 íbúa }\end{array}$ & 1,9 & 2,6 & $\mathbf{1 , 6}$ & 2,3 & 2,3 \\
\hline
\end{tabular}

Ýmislegt athyglisvert kemur fram í töflu 2. Fólksfjölgun á Íslandi er langtum meiri en á öðrum Norðurlöndum. Fæðingar- og dánartíðni hefur pó lækkað hérlendis undanfarna áratugi, m.a. vegna minni ungbarnadauða og aukinna atvinnutækifæra kvenna (Tryggvi Pór Herbertsson, Orszag J.M. \& Orszag P.R. 1999). Væntanlegur lífaldur er svipaður á Norðurlöndunum en barnadauði mjög lágur á Íslandi en hár í Danmörku. Hlutfall peirra sem ekki reykja er ekki ólíkt milli 
landanna en Danmörk sker sig úr með mikilli áfengisneyslu. Tíðni krabbameins er svipuð í löndunum fyrir utan Danmörku. Ísland er með flesta legudaga á sjúkrahúsi og er mikill munur á Íslandi og Finnlandi. Svípjóð sker sig úr hvað hjartaáföll varðar en legudagar vegna peirra eru langflestir hérlendis. Finnland er með hæstu tíðni sjálfsmorða. Fjöldi starfsmanna í heilbrigðispjónustu er mjög misjafn og eru hlutfallslega fæstir starfandi hérlendis en mun fleiri í Finnlandi.

Tafla 3. Útgjöld til heilbrigðismála á Norðurlöndum, aldurshlutfall og útgjöld að teknu tilliti til aldurssamsetningar

\begin{tabular}{|l|c|c|c|c|c|}
\hline & Danmörk & Finnland & Ísland & Noregur & Svípjóð \\
\hline $\begin{array}{l}\text { Útgjöld til heilbrigðismála sem hlutfall af } \\
\text { landsframleiðslu, (A) }\end{array}$ & 8,5 & 6,9 & $\mathbf{8 , 7}$ & 8,5 & 7,9 \\
\hline Aldurshlutfall (yfir 65 ára/20 til 64 ára), (B) & 24,3 & 21,4 & $\mathbf{2 0 , 3}$ & 26,7 & 30,1 \\
\hline Aldursleiðrétt hlutdeild útgjalda, (A/B) & 0,35 & 0,32 & $\mathbf{0 , 4 3}$ & 0,32 & 0,26 \\
\hline
\end{tabular}

Í töflu 3 eru sýnd útgjöld til heilbrigðismála á Norðurlöndum fyrir árið 1999 sem hlutfall af landsframleiðslu (OECD Health Data 2002). Par sést að hlutfallið er hæst hérlendis eða 8,7\%. Раð er lægst í Finnlandi, 6,9\%. Mikilvægt er að skoða aldurssamsetningu pjóðarinnar par sem almennt er talið að heilbrigðisútgjöld séu pví hærri peim mun fleiri sem eldri borgarar eru vegna pess að peir purfa meiri umönnun. Aldurssamsetning pjóðanna á Norðurlöndum er ólík. Pað eru fleiri eldri borgarar í Svípjóð og Noregi en annars staðar. Til að skýra petta er reiknað aldurshlutfall, p.e. hlutdeild eldri borgara yfir 65 ára deilt með hlutdeild peirra sem eru 20 til 64 ára (Tryggvi Pór Herbertsson, Orszag J.M. \& Orszag P.R. 1999). Sá stuðull, sem er sýndur í töflu 3, lýsir pví hvað pað eru margir eldri borgarar á hverja 100 einstaklinga á vinnufærum aldri frá 20 til 64 ára. Í Svípjóð eru peir 30,1 talsins en aðeins 20,3 hérlendis. Með pví að deila aldurshlutfalli, sem er pví hærra peim mun eldri sem pjóðin er, í útgjöld til heilbrigðismála sem hlutdeild af landsframleiðslu fæst betri mynd af útgjöldum og með pví er tekið tillit til mismunandi aldurssamsetningar. Slík aldursleiðrétt hlutdeild útgjalda er íneðstu línu í töflu 3. Ísland, sem ver mestu til heilbrigðismála sem hlutfalli af landsframleiðslu, ver tiltölulega enn meiru en aðrar Norðurlandapjóðir í pennan málaflokk vegna pess að hér eru mun færri eldri borgarar. Pegar tekið er tillit til pess að flestir eldri borgarar eru í Svípjóð eru útgjöld Svía tiltölulega lítil í samanburði við nágrannapjóðirnar. Muninn á útgjöldum Noregs og Finnlands má líklega skýra að stórum hluta með pví að í Noregi eru mun fleiri eldri borgarar en í Finnlandi. Рað parf hins vegar að hafa í huga að börn eru mun fleiri hérlendis og náttúrleg fjölgun mun meiri en í nágrannalöndunum og pað hefur í för með sér heilbrigðisútgjöld en hér er ekki sérstaklega leiðrétt fyrir fjölda barna.

Á mynd 7 sést ólík aldurssamsetning Íslendinga og annarra Evrópubúa (Ásgeir Jónsson 2002). Um 30\% Íslendinga eru undir 19 ára aldri en 23\% annarra Evrópubúa. Einungis 15\% Íslendinga eru yfir 60 ára aldri en 21\% annarra Evrópubúa. 


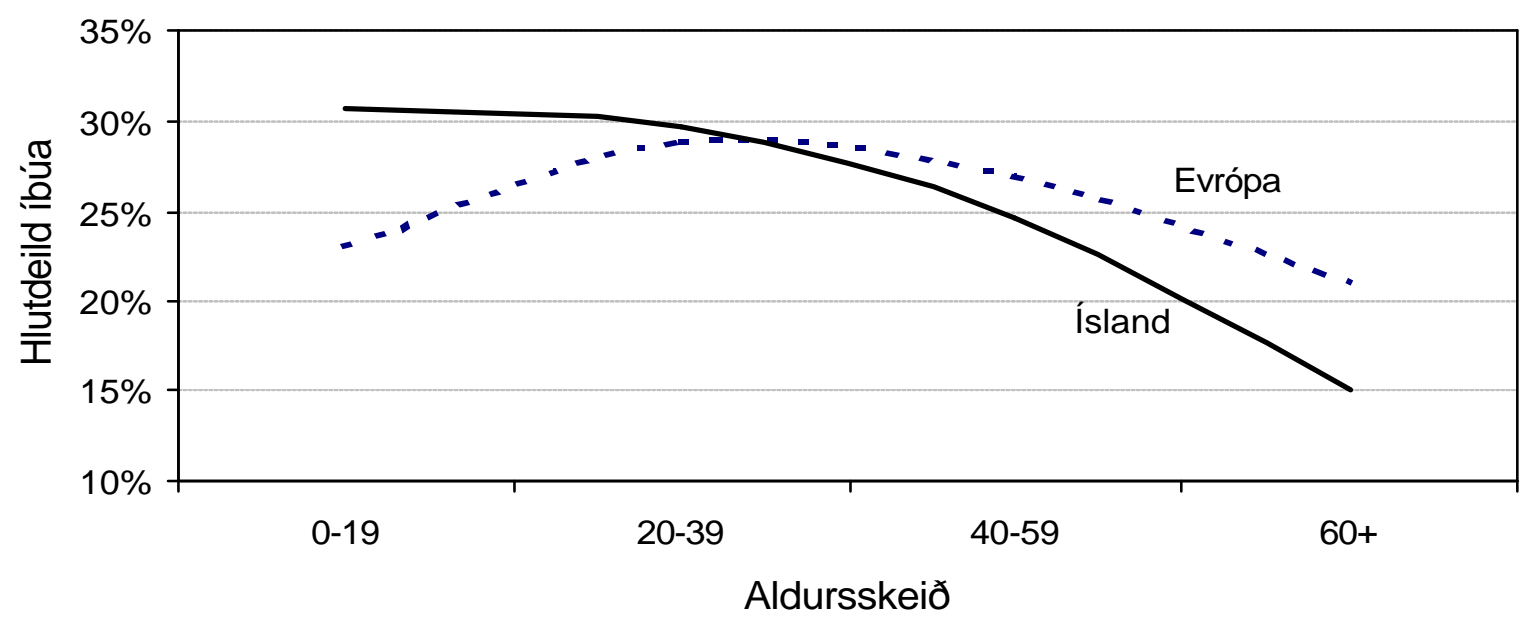

Mynd 7. Hlutfall íbúa á mismunandi aldursskeiðum í Evrópu og á Íslandi

Í töflu 4 er margvíslegur fjölpjóðlegur samanburður og er byggt á gögnum OECD (OECD in Figures 2002 og OECD Health Data 2002). Samanburður upplýsinganna í töflu 4 er ekki einhlítur vegna pess að mælingum getur að einhverju leyti verið hagað á mismunandi hátt í einstökum löndum. Við samanburð OECDlandanna er premur löndum sleppt, Kóreu, Mexíkó og Tyrklandi, vegna pess að staða peirra er langt frá öðrum OECD-löndum enda landsframleiðsla á íbúa lág í samanburði við önnur ríki OECD. Pessum upplýsingum er hér ætlað að veita vísbendingar um stöðu Íslands í samanburði við aðrar pjóðir og benda á margvísleg rannsóknarefni innan heilsuhagfræðinnar sem tengjast Íslandi. Í töflu 4 eru upplýsingar fyrir Ísland feitletraðar svo og hæsta og lægsta gildi fyrir einstök atriði.

Í 2. dálki í töflu 4 sjást útgjöld til heilbrigðismála sem hlutfall af landsframleiðslu árið 1999. Bandaríkin verja mestu til heilbrigðismála eða 13\% af landsframleiðslu. Ísland er í 6. sæti af 27 OECD-ríkjum með 8,7\%. Útgjöld til heilbrigðismála eru mjög stór hluti af útgjöldum best settu pjóða heims. Ísland, sem er með lægri opinber útgjöld til margra málaflokka en önnur lönd, einkum til velferðarmála, er með sambærilegan hlut og hærri en nágrannalöndin pegar kemur að heilbrigðismálum.

Í 3. dálki í töflu 4 sjást heildarútgjöld, bæði opinberra aðila og einkaaðila, til heilbrigðismála á hvern íbúa í bandarískum dollurum árið 1999. Notaður er jafnvirðiskvarði (Purchasing Power Parity, PPP) til að gera upphæðirnar sambærilegar milli landa. Bandaríkin verja langmestu til heilbrigðismála á hvern íbúa af 26 ríkjum OECD árið 1999, eða um fjögur púsund og fjögur hundruð dollurum. Ísland er í 4. sæti. Útgjöld til heilbrigðismála á hvern íbúa lýsa vel stöðu og forgangi pess málaflokks í einstökum löndum. Pótt Bandaríkin verji langmestu allra ríkja til heilbrigðismála á hvern íbúa verður að hafa í huga að útgjöldum til heilbrigðismála er par misskipt. Sá munur er minni hjá Evrópupjóðum enda er par annað kerfi sem byggist mikið á almannatryggingum en í Bandaríkjunum eru sjálfstæðar sjúkratryggingar stór páttur í heilbrigðiskerfinu. 
Tafla 4. Fjölpjóðlegar upplýsingar um heilbrigðismál OECD-ríkja

\begin{tabular}{|c|c|c|c|c|c|c|c|}
\hline Land & \begin{tabular}{|c|} 
Útgjöld til \\
heilbrigððs- \\
mála sem \\
hlutdeild af \\
landsfram- \\
leiðslu (1999)
\end{tabular} & \begin{tabular}{|c|} 
Útgjöld til \\
heilbrigð̃is- \\
mála á íbúa í \\
US \$ (PPP) \\
$(1999)$
\end{tabular} & $\begin{array}{c}\text { Opinber } \\
\text { útgjöld til } \\
\text { heilbrigðis- } \\
\text { mála sem } \\
\text { hlutdeild af } \\
\text { opinberum } \\
\text { heildar- } \\
\text { útgjöldum } \\
\text { (1999) }\end{array}$ & $\begin{array}{c}\text { Hlutdeild } \\
\text { íbúa yfir } 65 \\
\text { ára aldri } \\
(2000)\end{array}$ & $\begin{array}{c}\text { Fjöldi } \\
\text { lækna á } \\
\text { hverja } \\
1.000 \text { íbúa } \\
\text { (1999) }\end{array}$ & $\begin{array}{c}\text { Barnadauði } \\
\text { á hverjar } \\
1.000 \\
\text { fæòingar } \\
(2000)\end{array}$ & $\begin{array}{c}\text { Dauðaslys í } \\
\text { umferðinni á } \\
\text { hverja } \\
100.000 \\
\text { íbúa (2000) }\end{array}$ \\
\hline Austurríki & 8,1 & 2061 & 11.1 & 15,5 & 3 & 4,8 & 10 \\
\hline Ástralía & 8,5 & 2058 & 17,1 & 12,3 & 2,5 & 5,2 & 12 \\
\hline Bandaríkin & 13,0 & 4373 & 17.2 & 12.6 & 2,8 & 7,1 & 15 \\
\hline Belgía & 8,7 & 2144 & 12,3 & 16,6 & 3,8 & 5,2 & 14 \\
\hline Bretland & 7,1 & 1666 & 14,8 & 15,6 & 1,8 & 5,6 & 6 \\
\hline Danmörk & 8,5 & 2358 & 12,7 & 14,8 & 3,4 & 5,3 & 9 \\
\hline Finnland & 6,9 & 1605 & 10,5 & 15,0 & 3,1 & 3,8 & 8 \\
\hline Frakkland & 9,4 & 2226 & 13,7 & 16,1 & 3,0 & 4,5 & 14 \\
\hline Grikkland & 8,7 & 1375 & 9,2 & 16,7 & 4,4 & 6,1 & 20 \\
\hline Holland & 8,2 & 2172 & 12 & 13,6 & 3,1 & 5,1 & 7 \\
\hline Írland & 6,8 & 1752 & 15,9 & 11,2 & 2,3 & 5,9 & 11 \\
\hline Ísland & 8,7 & 2409 & 18,3 & 11,6 & 3,4 & 3,0 & 11 \\
\hline Ítalía & 7,8 & 1882 & 11,7 & 17,7 & 5,9 & 5,1 & 11 \\
\hline Japan & 7,4 & 1844 & 13.3 & 17,3 & 1,9 & 3,2 & 8 \\
\hline Kanada & 9,2 & 2428 & 14,8 & 12,5 & 2,1 & 5,3 & 10 \\
\hline Lúxemborg & 6,0 & 2613 & 13,2 & 14,3 & 3,1 & 5,1 & 17 \\
\hline Noregur & 8,5 & 2453 & 14,7 & 15,2 & 2,8 & 3,8 & 7 \\
\hline Nýja-Sjáland & 7,9 & 1526 & & 11,8 & 2,3 & 5,4 & 12 \\
\hline Portúgal & 8,4 & 1402 & 13,9 & 15,1 & 3,2 & 5,5 & 21 \\
\hline Pólland & 6,2 & 557 & 9,4 & 12,2 & 2,3 & 8,1 & 16 \\
\hline Slóvakía & 5,8 & & & 11,4 & & 8,6 & \\
\hline Spánn & 7,7 & 1469 & 12,4 & 16,8 & 3,1 & 4,6 & 15 \\
\hline Sviss & 10,7 & 3080 & 15,4 & 15,8 & 3,4 & 4,9 & 8 \\
\hline Svípjód & 7,9 & 1748 & 11,4 & 17,3 & 2,9 & 3,4 & 7 \\
\hline Tékkland & 7,2 & 972 & 14,2 & 13,8 & 3,0 & 4,1 & 14 \\
\hline Ungverjaland & 6,8 & 787 & & 14,7 & 3,2 & 9,2 & 12 \\
\hline Pýskaland & 10,3 & 2451 & 16,4 & 17,2 & 3,5 & 4,4 & 9 \\
\hline
\end{tabular}

Í 4. dálki í töflu 4 sést hversu stórum hlut af opinberum útgjöldum 24 OECDríkja er varið til heilbrigðismála árið 1999 fyrir langflest löndin. Á Íslandi var 18,3\% útgjaldanna varið í pennan málaflokk árið 1998 og var Ísland hæst innan OECD pað ár. Fátæk lönd innan OECD eru með innan við 10\% útgjalda sinna til heilbrigðismála. Hérlendis fara $54 \%$ opinberra útgjalda innan heilbrigðisgeirans til almennra sjúkrahúsa, 15\% til hjúkrunar og endurhæfingar, 15\% til heilsugæslu, 12\% í lyf og hjálpartæki og 4\% í annað (Búskapur hins opinbera 1999).

Í 5. dálki í töflu 4 sést hlutdeild íbúa yfir 65 ára aldri árið 2000. Aldurssamsetning milli pjóða heims er mjög mismunandi. Tiltölulega fáir eldri borgarar eru hérlendis. Um 11,6\% af íbúum Íslands eru yfir 65 ára aldri og er pað priðja lægsta hlutfallið meðal 27 ríkja OECD. Flestir fullorðnir eru á Ítalíu en par eru 17,7\% 1́búanna yfir 65 ára. Hjá pjóðum sem hafa mjög marga eldri borgara vega lífeyrisgjöld mjög pungt. Spár gera ráð fyrir að 22\% 1́búa verði yfir 65 ára aldri hérlendis innan 40 ára (Landshagir 2001). Aldurssamsetning pjóðfélaga er að breytast verulega og mun pað hafa margvíslegar afleiðingar í för með sér, sérstaklega hvað 
varðar heilbrigðispjónustuna. Pessi breyting er skemmra á veg komin hérlendis en í nágrannalöndunum.

Í 6. dálki í töflu 4 sést fjöldi lækna á hverja 1.000 íbúa í einstökum löndum árið 1999 en pað er oft talinn mælikvarði á heilbrigðispjónustuna. Рað á ekki eins vel við lengur par sem heilbrigðispjónusta er miklu fjölbreytilegri en áður, m.a. hvað varðar starfsfólk. Ísland er vel mannað af læknum miðað við aðrar pjóðir og er í 5. sæti af 26 OECD-ríkjum með 3,4 lækna á hverja 1.000 íbúa. Ítalía hefur flesta lækna á hverja 1.000 íbúa árið $1999(5,9)$ og par eru líka flestir yfir 65 ára aldri. Læknar lyftu grettistaki á síðustu öld í íslensku pjóðlífi og ber nafn priggja Guðmunda par hæst, Guðmundar Björnssonar, Guðmundar Hannessonar og Guðmundar Magnússonar. Ekki má pó gleyma Bjarna Pálssyni, fyrsta landlækninum, en störf hans í stóru landi, sem var mjög erfitt yfirferðar, eru í reynd kraftaverk.

Í 7. dálki í töflu 4 sést barnadauði árið 2000 en barnadauði er mjög mismunandi í heiminum. Hér er hann langminnstur, eða aðeins 3 látnir á hverjar 1.000 fæðingar. Lágur barnadauði hefur alltaf verið talinn lýsa góðu heilbrigðiskerfi. Barnadauði hefur lækkað hér mikið síðustu 10 ár. Árið 1989 var hann 5,9 af hverjum 1.000 fæddum börnum. Barnadauði er mjög mikið vandamál í fátækum löndum.

Í 8. dálki í töflu 4 sjást banaslys í umferðinni. Á árinu 2000 voru 11 dauðaslys í umferðinni á hverja 100.000 íbúa hérlendis. Ísland er í miðjum hópi OECD-ríkja viðmiðunarárið. Umferðarslys eru mjög kostnaðarsöm í hagkerfinu. Eignatjón er verulegt í umferðarslysum auk líkams- og sálarskaða slysapola. Umferðarslys eru alvarlegt efnahagslegt vandamál á Vesturlöndum (Kostnaður vegna umferðarslysa á Íslandi 1996).

\section{Tvívíður samanburður milli landa innan OECD}

Oft er pví haldið fram að bein línuleg tengsl séu á milli útgjalda til heilbrigðismála og peirrar heilbrigðispjónustu sem er veitt. Hins vegar kemur ljós að ekki er alltaf sérlega mikil fylgni á milli heilbrigðisútgjalda og árangurs í heilbrigðismálum ef hin próaðri OECD-lönd eru borin saman. En svo virðist sem nokkur munur sé á skilvirkni heilbrigðispjónustunnar á milli landa, sem hefur mun meira að segja um árangur heldur en útgjöldin ein og sér. Petta sést glögglega í tvívíðum samanburði á fylgni í línuritum og er byggt á upplýsingunum í töflu 4.

Par sem yfirleitt dregur úr heilbrigði fólks eftir að pað hefur náð eftirlaunaaldri ætti pörfin fyrir heilbrigðispjónustu að vera meiri í löndum par sem tiltölulega hátt hlutfall íbúa hefur náđ 65 ára aldri. Á mynd 8 eru einstök lönd sýnd og er hlutdeild íbúa yfir 65 ára aldri á x-ásnum og fjöldi lækna á hverja 1.000 íbúa á y-ásnum. Ísland er sérstaklega merkt svo og nokkur önnur lönd. Par sést vel að aukinn fjöldi eldri borgara kallar á aukna læknispjónustu. Hægt er að draga skýra leitnilínu og einföld aðfallsgreining bendir til pó nokkurrar fylgni. Hér sést t.d. að hlutfall eldri borgara á Ítalíu er mun hærra en á Íslandi, enda eru læknar mun fleiri á hverja púsund íbúa par en hérlendis. 


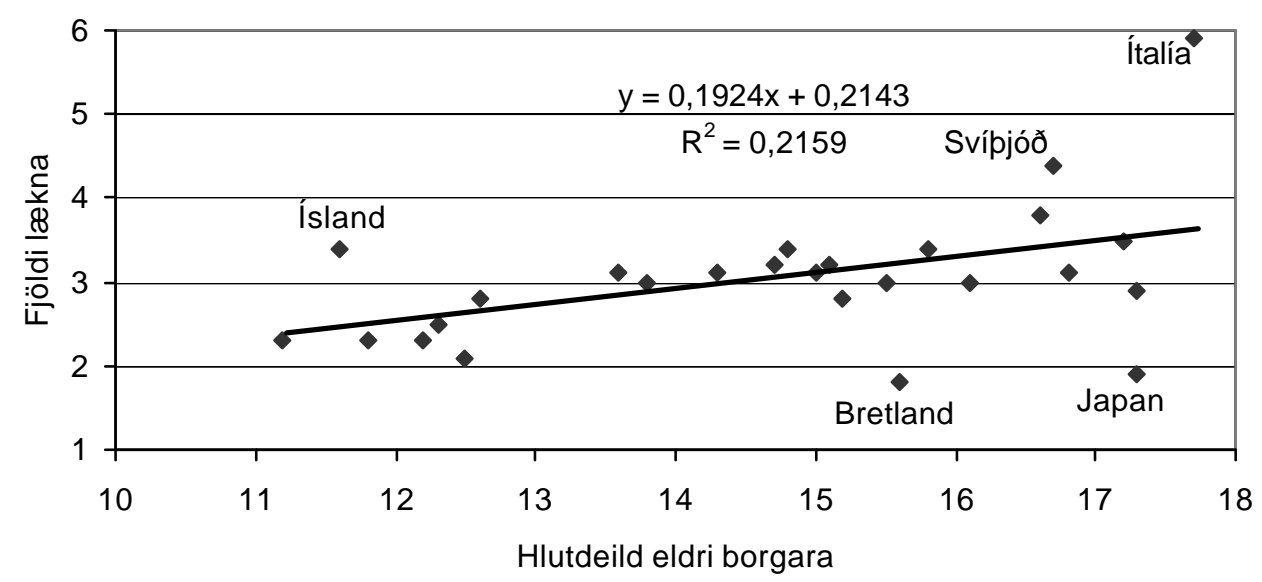

Mynd 8. Samband fjölda lækna og eldri borgara í 26 OECD-ríkjum

Ef aldurshlutfallið er aftur á móti borið saman við heilbrigðisútgjöld á íbúa, sem gert er á mynd 9, bregður öðru við og ekkert samband virðist vera par á milli.

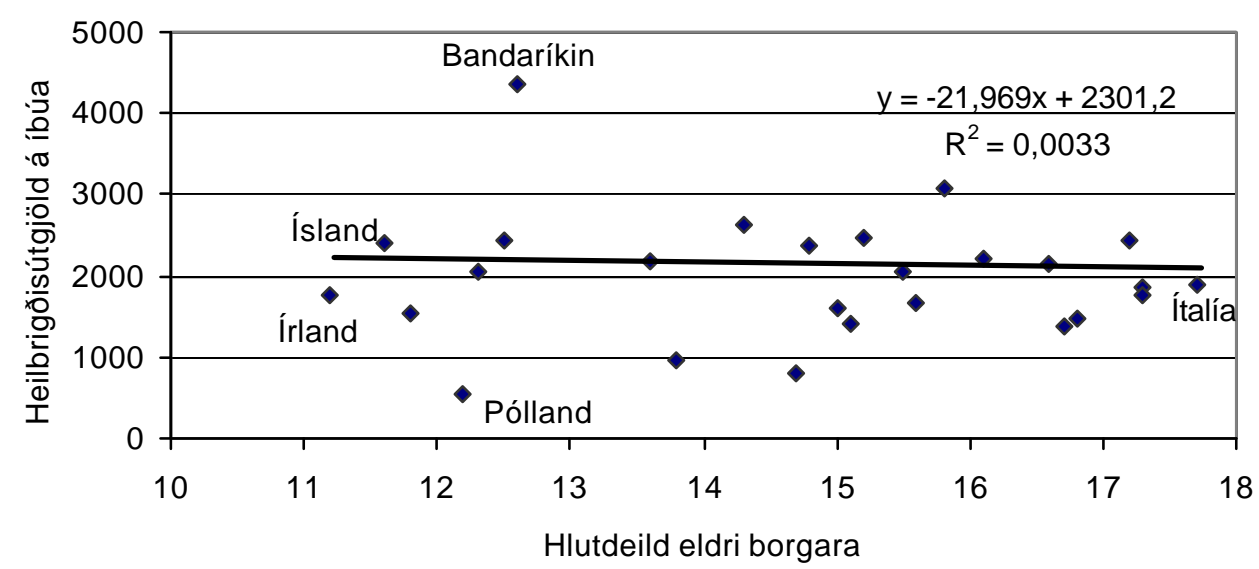

Mynd 9. Samband heilbrigðisútgjalda á íbúa í US \$ á jafnvirðiskvarða (PPP) og hlutfalls eldri borgara í 26 OECD-ríkjum

Ef leitnilína er dregin upp miðað við punktana er hún fullkomlega flöt og einföld aðfallsgreining gefur ekki til kynna neina fylgni. Ástæðan fyrir pessu er m.a. sú að skilvirkni heilbrigðispjónustunnar og umbun starfsfólks í heilbrigðisgreinum er mjög misjöfn á milli landa en laun eru einn stærsti hluti heilbrigðisútgjalda. Á mynd 9 sést t.d. að prátt fyrir að hlutfall fólks 65 ára og eldra sé mun hærra meðal ítölsku pjóðarinnar en peirrar íslensku eru heilbrigðisútgjöld par nokkuð lægri á hvern pegn en er á Íslandi. Parna sést einnig að heilbrigðiskerfið í Bandaríkjunum er algerlega sér á báti. Hlutfall fólks á eftirlaunaaldri er par tiltölulega lágt en heilbrigðisútgjöldin eru mjög mikil.

Útgjöld til heilbrigðismála skiptast í opinber útgjöld og einkaútgjöld. Einkaútgjöld eru hérlendis 15\% heildarútgjalda en pau eru 56\% í Bandaríkjunum. Yfirleitt er heilsupjónusta við aldraða að miklu leyti á ábyrgð opinberra aðila í flestum vestrænum ríkjum, pó reyndar í mismunandi mæli. Á mynd 10 eru opinber útgjöld til heilbrigðismála sem hlutfall af landsframleiðslu borin saman við aldursskiptingu og er ekki fylgni par á milli. 


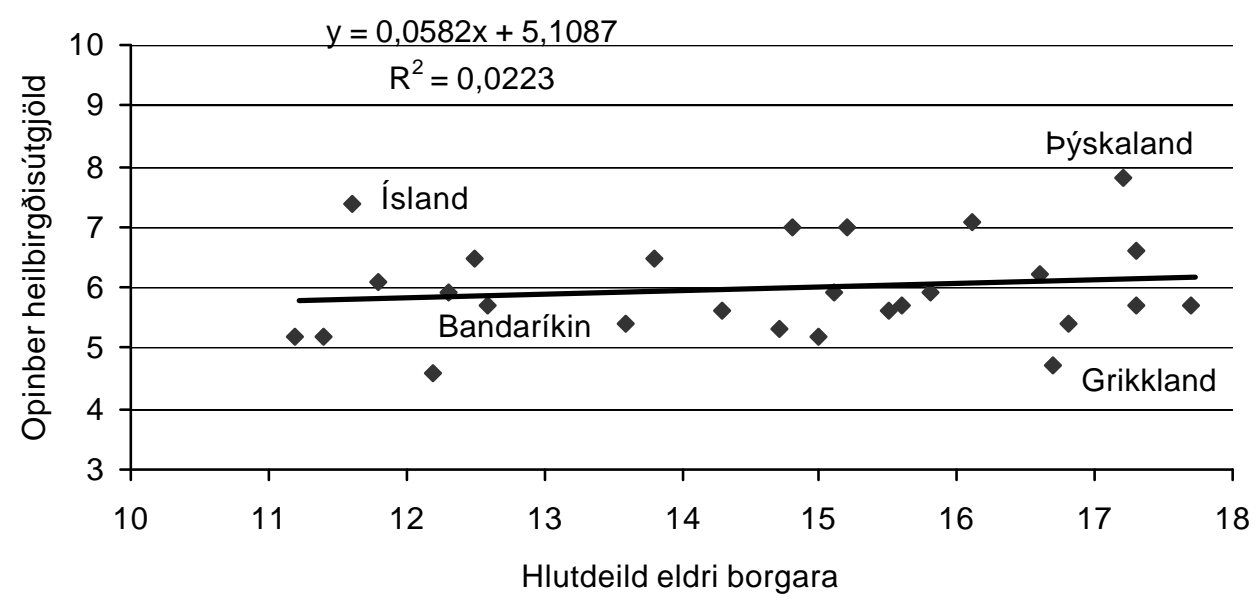

Mynd 10. Samband opinberra heilbrigðisútgjalda sem hlutdeild af landsframleiðslu og aldursskiptingar fyrir 27 OECD-ríki

Opinber útgjöld til heilbrigðismála á Íslandi eru næsthæst meðal OECD-ríkja pótt aldursskipting hér sé með pví hagstæðasta sem pekkist meðal pessara ríkja. Hér sést einnig að Bandaríkin eru ekki lengur í fjarlægð frá öðrum ríkjum, eins og var pegar heildarútgjöld voru tekin saman, p.e. pegar einkaútgjöld til heilbrigðismála eru ekki undanskilin. Рað er einnig greinilegt að landsframleiðsla á mann í viðkomandi ríkjum setur strangan ramma um útgjöld hins opinbera til heilbrigðispjónustu. Hægt er að bera saman tvö lönd með nær sama hlutfall eldra fólks, Grikkland og Pýskaland, en í síðartalda landinu eyðir hið opinbera tvöfalt meira á hvern íbúa til heilbrigðismála en pekkist í pví fyrrnefnda enda er landsframleiðsla á íbúa í Pýskalandi um 50\% hærri en er í Grikklandi.

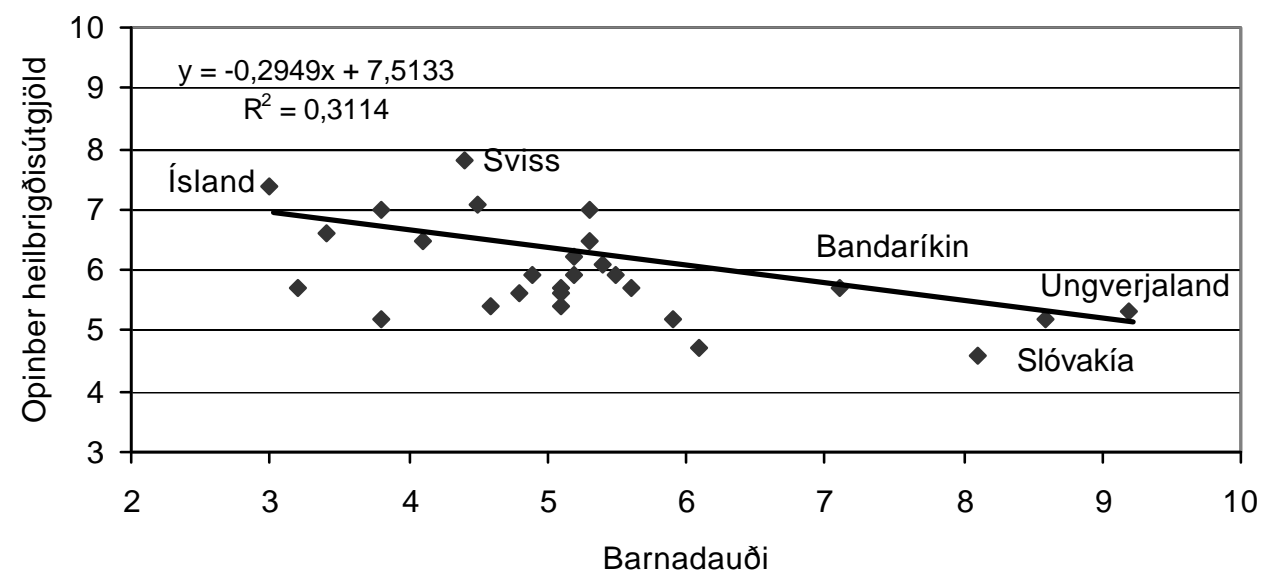

Mynd 11. Samband opinberra heilbrigðisútgjalda sem hlutfall af landsframleiðslu og barnadauða á hverjar 1.000 fæðingar í 27 OECDríkjum

Á mynd 11 eru útgjöld og árangur í heilbrigðiskerfinu borin saman með pví að birta saman ungbarnadauða og opinber útgjöld til heilbrigðismála sem hlutfall af landsframleiðslu. Раð er sterkt samband á milli ungbarnadauða og opinberra heilbrigðisútgjalda. Eftir pví sem hið opinbera ver stærri hluta af landsframleiðslu í heilbrigðismál peim mun minni er barnadauðinn. Ísland er með minnstan 
barnadauða innan OECD og hið opinbera ver hér miklu fjármagni til heilbrigðismála í samanburði við önnur lönd. Ungverjaland og Slóvenía eru með mestan barnadauða í pessum samanburði og opinber útgjöld peirra til heilbrigðismála eru tiltölulega lítil.

Myndirnar hér að framan sýna pá aðferðafræði sem notuð er innan heilsuhagfræðinnar til að bera saman pætti á einfaldan hátt milli landa. Breytingar innan landanna gæu hins vegar haft í för með sér aukin eða minni útgjöld til heilbrigðismála. Slíkan samanburð er hægt að greina nánar á einstökum sviðum og bera saman við fyrri stöðu. Mikil útgjöld eru ekki endilega trygging fyrir árangri.

\section{Matsaðferðir innan heilsuhagfræðinnar}

Pegar rætt er um hagfræðilegt mat innan heilsugæslunnar eru einkum fjórar leiðir farnar (Drummond et al. 1997, Blomqvist 2002 og Sorkin 1992). Pað er í fyrsta lagi greining á lágmarkskostnaði (cost-minimization analysis) sem er samanburður á verði aðgerða án pess að mat sé lagt á afleiðingar peirra. Í öðru lagi er pað greining á kostnaði og árangri, eða kostnaðarárangursgreining (cost-effectiveness analysis) eða kostnaðar-/virknigreining, par sem líffræðilegar einingar, t.d. viðbótarlífár, eru lagðar til grundvallar (Axel Hall 2002). Dæmi innan kostnaðarárangursgreiningar er að skoða viðbótarlíftíma á hverja eydda krónu eins og pegar barist er gegn inflúensu og árangurinn mældur í fækkun veikindadaga. Í priðja lagi er pað greining á kostnaði og nytjum, eða kostnaðarnytjagreining (cost-utility analysis) sem er samanburður á peim nytjum sem aðgerðir hafa í för með sér. Í kostnaðarnytjagreiningu felst að afleiðingarnar eru metnar fyrir einstaklinginn eða samfélagið í heild sem nytjar. Hér geta aðstæður verið mjög ólíkar. Sem dæmi má nefna eineggja tvíbura; annar er málari en hinn pýðandi og báðir handleggsbrotna. Pá er augljóst að afleiðingar pessa slyss eru mjög mismunandi. Málarinn getur ekkert unnið en petta hefur sáralítil áhrif á vinnu pýðandans og hann getur jafnvel stundað vinnu eins og áður. Kostur kostnaðarnytjagreiningar nýtist m.a. við samanburð á margpættum og ólíkum niðurstöðum af aðferðum. Við kostnaðarárangursgreiningu og kostnaðarnytjagreiningu er m.a. unnið með hlutföll, afurðir deilt með aðföngum. $\dot{I}$ fjórða lagi er pað greining á kostnaði og ábata, eða kostnaðarábatagreining (costbenefit analysis) par sem hagrænt mat er lagt á alla pætti, m.a. ytri áhrif.

Kostnaðarábatagreiningin er notuð víða. Í henni er lagt fjárhagslegt mat á allar afleiðingar til tekjuauka og dreginn frá allur kostnaður sem viðkomandi aðgerð hefur í för með sér. Раð liggur sjaldnast í augum uppi hvernig bera eigi saman afleiðingar. Mjög algeng mælieining innan heilsuhagfræðinnar er að meta hvað bætist við líftíma sjúklings (QALY: Quality-adjusted life years). Рað er mikilvægt í pessu sambandi að gæði viðbótarlífára séu metin par sem lítil hjálp er í pví að lengja lífið í sífelldum kvölum (Getzen 1997). Ábatinn er ávinningur mældur í peningum á tilteknu ári t. Síðan er metinn kostnaður á ári $t$ og er afvaxtað með reikningsvöxtum yfir allt tímabilið. Með pessum hætti fæst hinn hagræni ávinningur af einstökum aðgerðum. Ef fjármagn er takmarkað fæst með pessari aðferð forgangsröð aðgerða. Hægt er að taka dæmi af einstaklingi sem á að meðaltali 50 ár eftir ólifuð en síðan veikist hann og sjúkdómurinn getur leitt til pess að ævi hans styttist um 20 ár. Pá er væntanlegur líftími aðeins 30 ár en með tilteknum læknisfræðilegum aðgerðum væri hægt að lengja hann í 35 ár. Pá eru pessar aðferðir bornar saman kostnaðarlega. Annað dæmi 
um kostnaðarábatagreiningu er samanburður á sjúkrahúsmeðferð eða meðferð heima vegna sálræns sjúkdóms (Weisbrod, Test \& Stein 1980). Í pví tilvikinu var seinni leiðin betri. Hún var dýrari en árangursríkari vegna pess að sjúklingarnir gátu betur stundað vinnu. Vinnutekjurnar koma pá inn í greininguna sem ábati sem ekki var til að dreifa við sjúkrahúsdvölina.

Ytri áhrif koma t.d. fram í heilsugæslu á pann hátt að einstaklingur er reiðubúinn að greiða fyrir að aðrir verði bólusettir til pess að minni líkur séu á pví að hann smitist. Petta er dæmi um hvernig tiltekinn páttur í heilsugæslu hefur í för með sér vaxandi greiðsluvilja hjá öðrum. Upplýsingar um heilsufar geta verið verðmætar fyrir sjúkling og tryggingafélög. Hægt er að spyrja úrtak pjóðarinnar í skoðanakönnun hve mikið fólk myndi vilja borga í hærri sköttum fyrir nýjar aðgerðir í heilsugæslu til viðbótar peim sem fyrir eru. Petta er ein leiðin til að leggja mat á fyrirhugaðar breytingar innan heilbrigðispjónustunnar. Með pví að vinna úr pessum upplýsingum fest heildarvilji til greiðslu sem tengist viðkomandi aðgerð. Einfalt dæmi sýnir hvernig slíkt mat fer fram innan heilsuhagfræðinnar: Árni og Bjarni eru í sambærilegum störfum. Bjarni vinnur sér inn 100.000 kr. minna en Árni á ári en dauðsföll eru einu fleiri á hver púsund störfí vinnunni hjá Árna. Pá er hvert mannslíf metið á 100 milljónir. Tryggingafélög vinna oft út frá pessari aðferðafræði, t.d. við lífog slysatryggingar. Fjárhagslegt mat manna í starfi kemur líka mjög oft fram pegar menn slasast eða ef peir verða öryrkjar. Annað dæmi er um öryggisbúnað í búl: Gefið er að banaslysum fækki úr 10 í 5 fyrir hver 100 pús. manna ef pessi öryggisbúnaður er settur í bíla. Ef fólk er reiðubúið að greiða 6.000 kr. fyrir búnaðinn pýðir pað að 100 púsund manns myndu greiða, samkvæmt pessu, 600 milljónir króna og spara með pví 5 mannslíf. Раð pýðir að hvert mannslíf er metið á 120 milljónir króna. Upplýsingar innan heilbrigðisgeirans eru viðkvæmar og umræðan um hvernig persónuvernd er háttað hefur verið mikil hérlendis í tengslum við miðlægan gagnagrunn á heilbrigðissviði. Slík umræða fer einnig fram í umhverfi heilsuhagfræðinnar (Rizzo 2001).

\section{Lokaorð}

Hér hefur komið fram að heilsuhagfræðin er sérgrein innan hagfræðinnar par sem hægt er að beita hefðbundnum líkönum til skýringar pótt sviðið sem markast af lífi og dauða sé oft að ýmsu leyti ólíkt pví sem menn eiga að venjast innan hagfræðinnar. Heilbrigðispjónusta er stór páttur og vaxandi í hagkerfi okkar og mikið vinnuafl og fjármagn er bundið í henni sem sýnir ljóslega mikilvægi skipulagðra vinnubragða við skýringar og áætlanagerð. Staða Íslands í alpjóðlegu samhengi er mjög góð á mörgum sviðum heilbrigðispjónustunnar en miklu fjármagni er varið til hennar hérlendis í alpjóðlegum samanburði. Matsaðferðir sem hafa verið notaðar með góðum árangri á öðrum sviðum henta vel innan heilbrigðisgeirans. Pegar haft er í huga hversu ung pjóðin er stefnir í aukin útgjöld með hækkandi aldri.

Margvíslegar athuganir hafa verið gerðar innan heilsuhagfræðinnar sem eru áhugaverðar, m.a. vegna pess að sambærilegar úttektir gætu vel átt við íslenskar aðstæður. Má í pví sambandi nefna fimm nýlegar rannsóknir, p.e. á áhrifum af breyttu laga- og rekstrarumhverfi sjúkrahúsa (Salit, Fass \& Nowak 2002), á verulegum kostnaðarlækkunum vegna skipulagðrar aðstoðar við að leysa sálræn 
vandamál á vinnustöðum (Zuvekas et al. 2002), á áhrifum aðgerða gegn tóbaksreykingum unglinga á reykingar síðar á ævinni (Glied 2002), á hagrænum áhrifum biðlista innan heilbrigðisgeirans (Gravelle, Dusheiko \& Sutton 2002, og Cullis, Jones \& Propper 2000) og rannsókn á jafnræði í heilsugæslu í 10 Evrópulöndum (Ísland var ekki par á meðal) og Bandaríkjunum (Dooslaer et al. 2000).

Ákvarðanir um skipulag í heilbrigðismálum hérlendis eru að langmestu leyti í höndum opinberra aðila. Samstarf framkvæmdavaldsins og heilbrigðisstétta við stefnumótun hefur oft verið brösótt. Aðferðir heilsuhagfræðinnar gætu stuðlað að meiri pekkingu um heilbrigðismál og auðveldað ákvarðanatöku byggða á hagrænu mati á kostum. Eins og fram kemur í greininni er kostnaður við heilbrigðismál umtalsverður hérlendis. Matsaðferðir innan heilsuhagfræðinnar eru öflug tæki sem er ekki enn nægjanlega beitt hérlendis. Endurskipulagning á fjármögnunarkerfi á sjúkrahúsum er vænleg leið til að ná betur utan um kostnað á peim pætti heilsugæslunnar. Fleiri rannsóknir í samanburði milli landa á einstökum sviðum heilbrigðismála væru mjög gagnlegar fyrir frekari umræðu.

Heilbrigðismál hafa verið mikið til umfjöllunar á alpjóðlegum vettvangi og fjölmargar pjóðir vinna að stefnumörkun á pessu sviði (The World Health Report, 2001 og Vilborg Ingólfsdóttir 2001). Íslendingar vinna einnig eftir ákveðinni áætlun í heilbrigðismálum (Ingimar Einarsson 2001). Heilsuhagfræðin er mikilvægt tæki í framtíðinni í umfjöllun um heilbrigðismál en aukin menntun á pví sviði er forsenda pess.

\section{Heimildir}

Arrow, K.J. (1963). Uncertainty and the Welfare Economics of Medical Care. American Economic Review, 53 (5), 941-973.

Axel Hall (2002). Kostnaður-/virknigreining; Aðferðafræðin. Reykjavík: Óbirt handrit. Ágúst Einarsson (1999). •ættir í rekstrarhagfræði. 2. útgáfa. Reykjavík: Heimsljós. Ásgeir Jónsson (2002). Er nokkuð slæmt að skulda? Viðskiptablaðið, 9 (8).

Benedikt Árnason (1990). Heilbrigðisútgjöld 1960-1980. Fjármálatíđindi,37(3),202-19.

Blomqvist, A. (2002). QALYs, standard gambles, and the expected budget constraint. Journal of Health Economics, 21 (2), 181-195.

Búskapur hins opinbera (1999). Reykjavík: Pjóðhagsstofnun.

Chicon, M., Newbrander, W., Yamabana, H., Weber, A., Normand, C., Dror, D., et al. (1999). Modeling in health care finance. A compendium of quantitative techniques for health care financing. Geneva: International Labour Office.

Claxton, K. \& Thompson K.M. (2001). A dynamic programming approach to the efficient design of clinical trials. Journal of Health Economics, 20 (5), 797-822.

Clewer, A. \& Perkins, D. (1998). Economics for Health Care Management. London: Prentice Hall. 
Cullis, J.G., Jones P.R. \& Propper, C. (2002). Waiting list and medical treatment: analysis and policies. Í Culyer, A.J., Newhouse, A.J. (Eds.). Handbook of Health Economics. Amsterdam: Elsevier.

Davíð Á. Gunnarsson (1979). Framboð og eftirspurn eftir heilbrigðispjónustu. Fjármálatíđindi, 26 (1), 35-45.

Doorslaer, E., Wagstaff, A., van der Burg, H., Christiansen, T., De Graeve, D., Duchesne, I., et al. (2000). Equity in the delivery of health care in Europe and the US. Journal of Health Economics, 19 (5), 553-583.

Dóra Skúladóttir (1981). Athugun á nokkrum páttum heilbrigðispjónustu. Fjármálatíđindi, 28 (1), 34-55.

Drummond, M.F., O'Brien, B., Stoddard, G.L., \& Torrance, G.W. (1997). Method for the Economic Evaluation of Health Care Programmes. 2nd Edition. Oxford: Oxford University Press.

Fjármögnunarleiðir heilbrigđispjónustu (1998). Skýrsla nr. C98:11. Reykjavík: Hagfræðistofnun Háskóla Íslands.

Folland S., Goodman A.C., \& Stano M. (2001). The Economics of Health and Health Care. 3rd Edition. Upper Saddle River: Prentice Hall.

Frumvarp til fjárlaga 2003 (2002). Reykjavík: Alpingi.

Furubotn, E. G. \& Richter, R. (1997). Institutions and Economics Theory. The Contribution of the New Institutional Economics. Chicago: The University of Michigan Press.

Getzen, T.E. (1997). Health Economics. Fundamentals and Flow of Funds. New York: John Wiley \& Sons.

Glied, S. (2002). „,Youth tobacco control: reconciling theory and empirical evidence.“ Journal of Health Economics, 21 (1), 117-135.

Gravelle H., Dusheiko M. \& Sutton M. (2002). „,The demand for elective surgery in a public system: time and money prices in the UK National Health Service." Journal of Health Economics, 21 (3), 423-449.

Guðrún Högnadóttir (2001). Gæði og frampróun í heilbrigðispjónustu. Í Heilbrigðisping 1999. Framtíðarsýn í heilbrigđismálum. Reykjavík: Heilbrigðis- og tryggingamálaráðuneytið.

Health Statistics in the Nordic Countries 1999 (2001). Köbenhavn: Medico Statistical Committee.

Hjertqvist, J. (2002). The Health Care Revolution in Stockholm. Stockholm: Timbro.

Högni Óskarsson, Páll Torfi Önundarson \& Vilhelmína Haraldsdóttir (1996).

Gæðastjórnun lækna á Íslandi. Læknablaðið, 82 (1), 766-776.

Ingimar Einarsson (2001). Íslensk heilbrigðisáætlun til ársins 2005. Í Heilbrigðisping 1999. Framtíðarsýn í heilbrigðismálum. Reykjavík: Heilbrigðis- og

tryggingamálaráðuneytið. 
Kostnaður og tekjur pjóðfélagsins vegna áfengisneyslu árin 1985-1989 (1999). Skýrsla nr. C91:03. Reykjavík: Hagfræðistofnun Háskóla Íslands.

Kostnaður vegna sjóslysa á Íslandi (1998). Skýrsla nr. C98:07. Reykjavík: Hagfræðistofnun Háskóla Íslands.

Kostnaður vegna slysa á börnum á Íslandi (1999). Skýrsla nr. C99:04. Reykjavík: Hagfræðistofnun Háskóla Íslands.

Kostnaður vegna umferðarslysa á Íslandi (1996). Skýrsla nr. C96:03. Reykjavík: Hagfræðistofnun Háskóla Íslands.

Kristján Kristjánsson (1995). Hverjir eiga að bíta við útgarðana? Um forgangsröðun í heilbrigðiskerfinu. Læknablaðið, 81 (10), 707-726.

Landshagir (2001). Reykjavík: Pjóðhagsstofnun.

Magnús Pétursson (2001). Starfsmannastefna. Í Heilbrigðisping 1999. Framtíðarsýn í heilbrigðismálum. Reykjavík: Heilbrigðis- og tryggingamálaráðuneytið.

McPake B., Kumaranayake L. \& Normand C. (2002). Health Economics. An International Perspective. London: Routhledge.

Newhouse J.P. (2002). Why Is There A Quality Chasm? Health Affairs, 21 (4), 13-25.

OECD Health Data (2002). Paris: OECD.

OECD in Figures (2002). Paris: OECD.

Peningamál (2002). Ársfjórðungsrit Seðlabanka Íslands 2004/4. Reykjavík: Seðlabanki Íslands.

Phelps, C.E. (1997). Health Economics. 2nd Edition. Reading: Addison-Wesley.

Rizzo, R.F. (2001). Safeguarding genetic information: privacy, confidentiality and security. Í Davis J.B. The Social Economics of Health Care. London: Routledge.

Rutherford, S. (2000). The Poor and Their Money. Oxford: Oxford University Press.

Salit S., Fass S. \& Nowak M. (2002). Out of the Frying Pan: New York City Hospitals in an Age of Deregulation. Health Affairs, 21 (1), 127-139.

Santerra, R.E. \& Neun, S.P. (1996). Health Economics: Theories, Insights, and Industry Studies. Chicago: Irwin.

Seplaki, L. (1997). Economic Scarcity and Healthcare Quality. Tradeoffs in Delineations and Dilemmas. Aldershot: Dartmouth.

Sorkin, A.L. (1992) Health Economics. 3rd Edition. New York: Lexington Books.

Sólveig F. Jóhannsdóttir \& Tryggvi Pór Herbertsson (2002). Framreikningur heilbrigðisútgjalda. Reykjavík: Óbirt handrit.

Spree, R. (1986). Veränderungen des Todesursachen-Panorames und sozioökonomischer Wandel - Eine Fallstudie zum „Epidemiologischen Übergang“. Í Gäfgen, G. (Hrsg.). Ökonomie des Gesundheitswesens. Berlin: Duncker \& Humblot. Sögulegt yfirlit hagtalna (2001). Reykjavík: Pjóðhagsstofnun. 
Tannlæknadeild og arðsemi tannlæknamenntunar (1993). Skýrsla nr. C93:02. Reykjavík: Hagfræðistofnun Háskóla Íslands.

Tryggvi Pór Herbertsson, Orszag, J.M., \& Orszag, P.R. (1999). Population Dynamics and Convergence in Fertility Rates. Birkbeck College Working Papers, no. 2199.

London: Birkbeck College.

Um forgangsröðun í heilbrigðispjónustu (1997). Skýrsla nefndar Læknafélags

Íslands. Læknablaðið, Fylgirit 25.

Vilborg Ingólfsdóttir. Stefna Alpjóðaheilbrigðisstofnunarinnar um heilbrigði á 21. öldinni og Evrópuáætlun WHO: Heilsa 21 (2001). Í Heilbrigðisping 1999.

Framtíðarsýn íheilbrigðismálum. Reykjavík: Heilbrigðis- og tryggingamálaráðuneytið.

Vilhjálmur Árnason (1993). Siðfræði lífs og dauða. Reykjavík: Háskóli Íslands.

Rannsóknarstofnun í siðfræði.

Weisbrod, B.A., Test M.A. \& Stein L.I. (1980). Alternatives to mental hospital treatment: economic cost-benefit analysis. Arch. General Psychiatry, 37, 400-405.

Zuvekas, S.H., Regier, B.A., Rae, D.S., Rupp, A., \& Narrow, W.E. (2002). The impacts of mental health parity and managed care in one large employer group. Health Affairs, 21 (3), 148-159.

Porgeir Pálsson \& Ásmundur Brekkan (1999). Fjarlækningar. Upplýsingatækni og skipulagning. Læknablaðið, 85 (11), 876-882.

Práinn Eggertsson (1990). Economic Behavior and Institutions. Cambridge: Cambridge University Press.

300 stærstu (2002). Frjáls verslun, 64(8). Reykjavík: Heimur. 
